\title{
Research on the Influence Mechanism of Disabled Staff Performance from the Perspective of Advantages
}

\section{-A Grounded Research Based on Shenzhen Canyou Company}

\author{
Wei Zhang, Xiaode Zuo, Shuran Li, Han Wu \\ School of Management, Jinan University, Guangzhou, China \\ Email:1814745454@qq.com
}

How to cite this paper: Zhang, W., Zuo, X. D., Li, S. R., \& Wu, H. (2020). Research on the Influence Mechanism of Disabled Staff Performance from the Perspective of Advantages. American Journal of Industrial and Business Management, 10, 564-584. https://doi.org/10.4236/ajibm.2020.103038

Received: June 15, 2018

Accepted: March 13, 2020

Published: March 16, 2020

Copyright $\odot 2020$ by author(s) and Scientific Research Publishing Inc. This work is licensed under the Creative Commons Attribution International License (CC BY 4.0).

http://creativecommons.org/licenses/by/4.0/

\begin{abstract}
From the perspective of superiority, this article is based on the theory of leadership style, using grounded theory research methods to explore and analyze the impact mechanism of disabled employees' performance in the local environment. The research results show that: 1) Spiritual leaders can influence their performance by improving the organizational commitment and organizational self-esteem of disabled employees. 2) The influence of spiritual leaders on the performance of disabled employees is affected by organizational support. The research findings reveal the "black box" of the performance impact mechanism of employees with disabilities, enrich and supplement the existing leader theory, provide a preliminary theoretical framework for follow-up related empirical research, and provide theory for organizations to stimulate disability employee performance in management practice.
\end{abstract}

\section{Keywords}

Leadership, Performance of Disabled Employees, Organizational Support, Organizational Commitment, Organizational Self-Esteem

\section{Introduction}

Studies have shown that people with disabilities have the same ability to work as others under pressure and are fully qualified for work. Families and employers of the disabled should have more confidence in them. However, China has been adopting a problem perspective model in the employment of disabled persons for a long time, which can easily lead to the disabled being labeled as incompe- 
tent. This makes it easy for disabled people to lose their optimistic expectations of their future and become self-defeating. Different from "unemployed" employment that is linked to the father's generation, the society needs to begin to focus on their own capabilities and strengths, and to use the advantages to promote their self-improvement and development. The academic community has discussed the issue of employment of deformities from various perspectives and has produced many valuable research results. However, the existing literature mostly uses sociological and psychological theories to explore how to increase the employment rate of disabled people. Few scholars conduct research on the situation of deformities within the company. This paper aims to explore effective leadership for disabled people in China's local context and discuss how to promote the performance of disabled employees through effective leadership, which is a research field with great theoretical and practical value.

The article is organized as follows: the first chapter is a literature review; the second chapter is research methods and research design; the third chapter is ideas based on grounded theory; the fourth chapter is conceptual integration and model; and the fifth chapter is research significance and management inspiration. From the perspective of advantageous, this paper introduces theoretical results, such as organizational support, organizational self-esteem, organizational commitment, and grounded theory research methods, which tries to provide new ideas and paradigms for the employment problem of disabled persons in China.

\section{Theoretical Review}

\subsection{Advantage Perspective}

"Advantageous perspective" is a social work's thinking method and working method, which is focus on people's inner strength, provides people with a new practice orientation. Dennis Saleebey clearly stated: the advantageous perspective is a dramatic leap forward to the practice of traditional social work. It's orientation actually means that everything that a social worker should do depends, to a certain extent, on finding, seeking, exploring and using the Lord's strengths and resources to help them achieve their goals, realize their dreams, face the frustrations and misfortunes in their lives, and resist the social mainstream's control (Saleebey, 1996).

The practice of an advantageous perspective requires us to view the object, their environment, and their current situation from a completely different perspective. Instead of focusing on problems with encouragement or focus, we focus on possibilities. In the thorns of trauma, pain, and suffering, you can see the seeds of hope and transformation, so that the object of the case will have a better quality of life. The "advantageous perspective" is based on an understanding of the subjective initiative of people. He believes that people are not passive but have their own potential and advantages, and can solve problems through their own potential and advantages. The basic beliefs of the advantage perspective in- 
clude: empowerment, membership, resilience, dialogue and cooperation, healing and integration, suspension suspicion.

Introducing the concept of an advantageous perspective into the management of disabled employees is an innovation from traditional management methods. It helps us to understand disabled employees more fully, respects disabled employees, and fosters the self-growth potential of disabled employees with equality and mutual assistance so that they can recognize their own advantages and resources, improve their problem solving capabilities, and make better contributions to social progress and development.

\subsection{Leadership Theory}

Leadership theory has always been one of the focuses of the organization management field. With the continuous change of organizational environment and new challenges, leadership theory has also evolved. Prior to the 20th century, the big man approach to leadership dominated leadership theory. After the 20th century, the theory of Leading Individual Traits also appeared. The findings of Stogdill and Myers show that there is no substantial relationship between leadership and physical characteristics (Stogdill, 1948). In the 1950s, the group leadership proposed by Whyte was more influential. Early experimental research at the University of Ohio and Michigan started the study of modern leaders. At the same time, behavioral leadership methods have gradually become more influential. Afterwards, emphasis is placed on different situations and varies from person to person. Context-based leadership methods gradually build up corresponding theories, such as the Pathway-target Leadership Theory. In the late 1990s, new leadership paradigms emerged: Shared leadership, Ethical leadership, Cultural leadership, Service leadership, Charismatic leadership theory, Spiritual leadership, etc.

In general, leadership has a special impact on the organization and employees. Employees will have respect, recognition, and affection for the leaders (this effect is especially significant in China). In addition, the norms that the leader establishes influence the organization's management practices. The work responsibilities of the employees are stipulated, and behavior outside the role is also influenced through role models and work environments. Therefore, leadership has a great influence on the employees' behavior.

\subsection{Work Performance}

In the Oxford English-Chinese Dictionary, performance refers to "behavior and working conditions." In the field of management, the research perspective of performance is not the same. Bernadin \& Beatty believes that work performance is the completion of work tasks defined in job descriptions and is a direct result of individual behavior (Bernardin \& Beatty, 1984). After the 1990s, scholars began to question the concept of performance and thought that over-emphasizing the results would lead to the neglect of other important factors in the work 
process. Therefore, it was proposed that performance is a behavioral process and conduct behavioral research on job performance. In recent decades, scholars have made more detailed divisions of research on job performance. They not only integrated the viewpoints of results and behavior, but also included personality characteristics and abilities into the study to continuously enrich the connotation of work performance.

The pluralistic nature at the individual level opens the field of view structure of performance as multi-dimension. Katz and Kahn classified the performance structure based on a behavioral perspective firstly. They examine the behavior and performance of individuals in the organization from three aspects: joining and staying in the organization, completing role tasks, showing active behavior, or innovating (Katz \& Kahn, 1966). This structural division actually divides the performance behavior into two types. One is the work task clearly specified in the job description, and the other is the individual self-issuance activity, which is beneficial but not explicitly requested by the organization. Subsequently, Borman etc. proposed the "soldier effectiveness model" and concluded that individual job performance evaluation includes not only the completion of their own tasks, but also the three aspects of loyalty, determination, and collaboration (Borman, 1993). On this basis, Organan and other scholars proposed organizational citizenship behavior in 1988. They believe that the organizational citizenship behavior is a Self-issued which has not been explicitly recognized by the formal reward system. However, such behavior will generally increase the effectiveness of the organization and belongs to the extra-role behavior in individual job performance. Since then, scholars have continuously enriched and developed the structural model of work performance based on the above studies (Clive, 2011).

Job performance can be divided into multiple levels such as organization, team, and individual. For any organization, pursuing the maximization of organizational effectiveness is always the goal, and organizational effectiveness is mainly achieved through the individual's work performance in the organization. Therefore, this study explores the individual work performance of employees in an organization by reviewing the corresponding literature, i.e., employee performance.

\section{Research Methods and Design}

\subsection{Research Methods}

The subject of this article is individual behavior and complex psychological phenomena, and is an exploratory nature. Therefore, A Single Case Grounded Research method was used. The single case study is suitable for in-depth examination of the complex and specific problems in the real world to explore potential theoretical contributions.

At present, there are two different schools of grounded theory: one is the grounded theory of objectivism represented by Glase, who believes that the core 
meaning of grounded theory lies in the data itself, and advocates discovering theories in the "natural presentation" of data and seeking to break away from the situation (Motowidlo \& Van Scotter, 1994). The grounded theory of Glaser etc. is a kind of objectivist research based entirely on data, belonging to the positivist category; the other school is the constructivism grounded theory represented by Charmaz. Based on the research of Strauss \& Corbin, it integrates "objective emergence" and "subjective interpretation", focuses on the process of data generation, emphasizes the fusion of the horizons of researchers and research subjects, and believes that grounded research is "in the context of interaction. It is aimed to construct meanings and actions in specific contexts and belong to the category of hermeneutics (Charmaz, 2009).

\subsection{Data sampling and Case Background}

This study uses a theoretical sampling method to select samples, that is, according to the study intention to select representative interviewees, so that the conclusions obtained are more interpretive. According to the typicality and availability of theoretical sampling, this article selects the Shenzhen Canyou company as the case study of the rooted study.

Shenzhen Canyou company is the only high-tech enterprise in the world that is entirely self-managed and self-develops by people with disabilities. It is called China's most successful social enterprise. In 1999, the founder of the Canyou company created a "dismembered friend" at his own home in Shenzhen. From a five disabled people and one computers mall workshops, he developed his own operations without relying on any foreign capital assistance. In 2009, the Canyou company was established and became a social enterprise with 32 social enterprises including software, animation, science and technology, e-commerce, and a net society, 8 social organizations, 1 foundation, and more than 5,000 employees. It not only radiated from Shenzhen to Hainan and Beijing, Shanghai, Hunan and other provinces and cities, but also extended to Hong Kong and Taiwan. Its business has become international and is preparing large-scale group listed on the social enterprise board. Canyou implements a self-management model in which the chairman, the general manager, and middle-level cadres are all served by people with disabilities. Successfully practiced the "harmonious science and technology business" in which people with disabilities made use of the computer Internet to create mutual assistance and development for the people's livelihood and high-tech industries in the era of new knowledge economy. Within the Canyou group, several founding leaders have an irreplaceable position in the hearts of those disabled employees. They all regard the company as their "home" and are willing to give their strength to the development of this extended family, which reflects the role of leaders on the performance of disabled employees. In view of this, this article believes that it is appropriate to conduct rooted research on Canyou company as a typical case sample, and to analysis the internal management of it in-depth. 


\subsection{Research Sample Collection and Organization}

In order to improve the validity of the research, this paper mainly adopts the "triangulation method" that obtains research materials from multiple information sources. Specifically, the data sources and collection methods of this article mainly include: 1) In-depth interviews. In-depth interviews are the main sources of data for this article. In order to ensure that the interviews are closely related to the research topics, semi-structured interviews are used in this paper. The interview steps are as follows: First, two different interview outlines are designed for different respondents (leaders and employees). Then, conduct in-depth interviews based on the outline. A total of 518 minutes of interview time were used to sort out 104,873 words of written materials. 2) Company portal information and text information, as well as newspaper and magazine reports. The researchers classify and organize them to form a text material of 59,700 words. 3) On-site observation. During the investigation, the researchers went deep into the enterprise, observed the work site, compiled a memorandum, and supplemented and verified each other with other data. Researchers collect data at the same time, conduct preliminary collation and analysis, and repeatedly compare old and new data to guide the next step in data collection. When data cannot generate new generics or concepts, data collection has reached saturation and is suspended. Table 1 shows the information of samples.

\subsection{Data Processing and Analysis}

This study uses semi-structured forms to conduct in-depth interviews with interviewees. The interview outline is used to guide the interview process, so that the entire process revolves around the research topics. However, the problems in the interview are not limited to this, and they will be adjusted appropriately in light of the on-site situation. Before conducting formal interviews, researchers will contact the respondents through telephone to establish preliminary contact between researchers and respondents to eliminate some of the communication

Table 1. Sample information.

\begin{tabular}{ccccc}
\hline Name & Sex & Age & Work year & Position \\
\hline M1 & male & 62 & 20 & Chairman \\
M2 & male & 44 & 20 & Deputy Chairman \\
M3 & male & 45 & 20 & Chief Technology Officer \\
E1 & male & 32 & 4 & Technician \\
E2 & male & 33 & 4 & Technician \\
E3 & male & 38 & 7 & Technician \\
E4 & male & 26 & 1 & Technician \\
E5 & female & 29 & 3 & Administration staff \\
E6 & female & 35 & 6 & Administration staff \\
\hline
\end{tabular}


barriers. At the same time, through the preparatory work for the interview, the interviewee can be encouraged to summarize and reflect on his own workplace experience and make preparations for formal interviews to ensure the feasibility and effectiveness of formal interviews. After the interview, the research team converted the collected audio files into texts and strictly followed the definition and characteristics of the leadership and employee performance.

In the coding, this study strictly follows the progressive coding of Strauss and other technical programs for conceptual and category induction and relationship construction. The details are as follows: 1). Form a coding team. In order to avoid the subjective knowledge of coding caused by the coder's knowledge structure, members of the research team perform their own data labeling and coding work; 2). Establish a research memorandum. Create a memo for each sample in the Excel spreadsheet to record the sample's encoding result and the modification process; 3 ). Comparative analysis. The concepts and categories that have been formed have a guiding role in the coding of subsequent data. When new concepts and categories are discovered, they are compared with the already-encoded results. Some of them even return to the concept and scope of data correction. This kind of spiral comparison analysis can make the concept and category of inductive refinement and the relationship between categories continue to be accurate and precise; 4) Theoretical saturation test. It should be pointed out that for the problems and differences existing in each stage of coding, re-encoded data, repeated spiral comparisons, and joint discussions are used to reach consensus.

\section{Ideas Based on Grounded Theory}

\subsection{Leadership}

To explore the specific connotation of the leadership of Canyou, it is necessary to determine the relevant concept features. Through the coding analysis, the concepts of the initial coding phase were integrated, and 3 sub-categories and 10 core concepts were obtained, as shown in Tables 2-4. On this basis, the researchers returned to the original data again and collected new data, trying to find out other areas that could reflect the leadership. Through the analysis of materials, new concepts and core generics have not yet been discovered. The concept category of leadership has reached saturation. As shown in Tables 2-4.

The coding results in Tables 2-4 show that Canyou's leadership style includes three dimensions: spirit \& vision, belief and altruism love. The spirit \& vision describes the future prospects for the development of the organization. Such a vision can motivate employees to be willing to contribute to the organization's goals. The spirit of the leader and his focus on the employees' spirit is the environment that enables the vision to breed. Belief is the degree of certainty and self-confidence that a leader has to aspire to achieve or depend on but not yet achieved. On the one hand, leaders have a firm belief in employees with disabilities. On the other hand, leaders encourage employees with disabilities to make 
Table 2. Spirit and vision.

\begin{tabular}{|c|c|c|}
\hline Subcategory & Core category & Initial code example \\
\hline & The spirit of the leader & $\begin{array}{l}\text { M2-23. People are not easy to die, and death is not easy, but between the two } \\
\text { points, we must do something, and this process is the realization of the value of } \\
\text { life; M1-104. My daughter has graduated from college work, she cannot rely on } \\
\text { me to live, but these properties can make many disabled people live happy and } \\
\text { dignified; } \\
\text { M3-18. Death has been my driving force and I urge myself to work harder for a } \\
\text { limited time. }\end{array}$ \\
\hline & Vision that is relevant to employees & $\begin{array}{l}\text { M2-20. Through wisdom training, ability enhancement, confirmation and } \\
\text { success in the shortcomings, and strive to be respected, we are aimed to build a } \\
\text { platform for serving people with high service value; M1-5. To "change another } \\
\text { way of life" in my rest of life and those people with disabilities who live without } \\
\text { self-esteem like me, I am determined to create such a platform by making }\end{array}$ \\
\hline
\end{tabular}

Spirit and Vision

Pay attention to employees' spiritual life

Communication of corporate vision
M2-4. There are some handicapped employees who are still not married, or are psychologically uncomfortable. We will have psychological counseling; M1-10. We are not saying that we are all disabilities, so we use the culture of the handicapped, I think everyone, regardless a disabled person or a healthy person, your first criterion for living is a citizen's standard, a standard for social citizenship; N-3.There is a long list of family members hangs on the walls: be grateful, treat each other with respect, respect others, be humble, harmonious, generous, caring for his comrades, brave to take responsibility, cherishing possession, a province a day, and so on.

M1-13. I often say to employees that why we do for this is actually very simple. It is to create a platform that allows people with disabilities like us to have the opportunity to come out through this platform; M1-24.Through the Canyou, we can achieve: employment, happiness, and stability.

Note: $\mathrm{M}$ stands for manager, $\mathrm{E}$ stands for employee, and $\mathrm{N}$ stands for newspaper and magazine. The post-letter number represents the original statement of the number of respondents and the position of the original statement in the content of the individual interview.

Table 3. Brief.

\begin{tabular}{|c|c|c|}
\hline Subcategory & Core category & Initial code example \\
\hline \multirow{3}{*}{ Brief } & Inner belief & $\begin{array}{l}\text { M2-47. disabled people do not have a way out. As long as there is a chance, } \\
\text { they must not give up. They must do their best to do things; M3-11. The "lone- } \\
\text { liness" of disabilities has prompted them to have a more active brain, a tougher } \\
\text { personality, more diligent quality, and more creative ideas; M1-30 I believe that } \\
\text { the Internet is opening up a new employment space for handicapped people. }\end{array}$ \\
\hline & Inspire employees with disabilities & $\begin{array}{l}\text { M2-35. The more disabled I am, the more beautiful I need to be. I often use } \\
\text { Zhang Haidi's phrase to encourage myself and his colleagues. M1-55. When } \\
\text { you want to succeed, the world will make way for you. "This is what I often say } \\
\text { to the disabled. } \\
\mathrm{N}-5 \text {. He kept repeating the sentence to the cruel friends around him: He } \\
\text { thought that he was not good enough. He was the biggest lie; he believed that } \\
\text { he had no value and was the biggest deception. }\end{array}$ \\
\hline & Great confidence in employees & $\begin{array}{l}\text { M1-34. With the exception of the body, they have nothing special, and people } \\
\text { with disabilities are no worse than healthy people; M1-59. As long as there is a } \\
\text { suitable platform, they can also exert their creativity and talents. M3-42. The } \\
\text { door closed by Heaven will surely open another door for disabled people. }\end{array}$ \\
\hline
\end{tabular}

Note: $\mathrm{M}$ stands for manager, $\mathrm{E}$ stands for employee, and $\mathrm{N}$ stands for newspaper and magazine. The post-letter number represents the original statement of the number of respondents and the position of the original statement in the content of the individual interview. 
Table 4. Altruistic love.

\begin{tabular}{|c|c|c|}
\hline Subcategory & Core category & Initial code example \\
\hline \multirow{4}{*}{ Altruistic love } & Put himself in employees' place & $\begin{array}{l}\text { M2-73. It does not mean that you are disabled and take care of you. In this } \\
\text { case, you will have more dignity when you get your position, and you will not } \\
\text { feel taken care of and be discriminated against; } \mathrm{N}-3 \text {. In general, there will be a } \\
\text { mildly disabled person at the upper level to facilitate the care of severely dis- } \\
\text { abled patients. }\end{array}$ \\
\hline & $\begin{array}{l}\text { Consider the overall situation } \\
\text { of the company }\end{array}$ & $\begin{array}{l}\text { M1-102. I did not pass it to someone behind me, but to the system of an inter- } \\
\text { nal cycle of the Trinity; N-2. He donated more than } 90 \% \text { of the assets of his } \\
\text { group of disabled friends to the Wing You Charitable Foundation, which is } \\
\text { used to develop the employment of persons with disabilities in high-tech fields. }\end{array}$ \\
\hline & Respect the families of employees & $\begin{array}{l}\text { M2-62. All the parents of our employees come to our company, or come to the } \\
\text { company to see them. The top leader of the company must accompany his } \\
\text { parents to eat. The Supreme Leader is not the second to accompany them to } \\
\text { eat, it must be the highest; M1- } 49 \text {. Set a home visit day every week, the door } \\
\text { must bring a bag of noodles, a barrel of oil }\end{array}$ \\
\hline & Teach employees to care for others & $\begin{array}{l}\text { M1-70. Customers, volunteers, and friends come to the door when they are } \\
\text { convenient. When they leave, they can send one and send them. No need to say } \\
\text { anything, just a heart; M3-54. When you encounter a colleague asking you } \\
\text { some questions, try to help answer them. If you can't answer them, try to give } \\
\text { your own advice }\end{array}$ \\
\hline
\end{tabular}

Note: $\mathrm{M}$ stands for manager, $\mathrm{E}$ stands for employee, and $\mathrm{N}$ stands for newspaper and magazine. The post-letter number represents the original statement of the number of respondents and the position of the original statement in the content of the individual interview.

themselves believe in themselves, fully reflects the leader's confidence in the organization's vision; and altruistic love not only reflects that the leader care for disabled employees' work and life, but also reflects his care for other factors closely related to the lives of employees. This coded result also reflects that the Canyou' leaders intrinsically motivate their employees through their own attitudes, values, and behaviors, create a common vision for individuals and organizations, and build a firm belief in the process of creating an atmosphere based on altruistic love.

Fry pointed out that spirit leadership refers to the sum of values, attitudes, and behaviors that are needed internally to motivate oneself and others so that they can have a sense of spiritual presence based on mission and membership, which is highly consistent with the result of us (Brown et al., 1986). So this article defines the leadership style of the Canyou Group as spiritual leadership. In terms of the structural dimension division of spiritual leaders, this article is also basically consistent with Fry's point of view.

\subsection{Work Performance}

To understand the performance of the employees of Canyou, it needs to be defined to reflect the scope of employee performance. Researchers coded and analyzed the qualitative data related to employee performance. Through the conceptualization and categorization of materials, the main category and subcategory were identified, and a main category, 2 subcategories, and 5 core codes were obtained. 
The coding results in Table 5 show that the performance of disabled employees can be specifically divided into two dimensions. One is the task performance dimension that is actively and enthusiastically completed in the work within the position, and the other is the peripheral performance that is actively undertaken for the job outside the position. Task performance is directly related to the output of work, while peripheral performance is not, but it also reflects the employees' feelings and attitude towards the organization. This coding result is consistent with the two-dimensional classification of job performance by Borman \& Motowidlo (1997).

\subsection{The Mechanism of Leadership Influence Performance of Disabled}

Through the above analysis, it has been cleared that the leadership of Canyou includes three dimensions: spirit \& vision, belief and altruism love. How do these three dimensions play a driving role and effectively improve employee performance? The researchers coded and analyzed the relevant qualitative data on the question of how the leadership style can improve the performance of disabled employees. Through the conceptualization and categorization of materials, the concepts and main categories were identified. Coding analysis finally got three main categories.

Table 5. Work performance.

\begin{tabular}{|c|c|c|c|}
\hline Main code & Subcategory & Core category & Initial code example \\
\hline & & $\begin{array}{l}\text { Complete work tasks } \\
\text { ahead of schedule }\end{array}$ & $\begin{array}{l}\text { M2-70. Others arranged a one-year study, and we finished our studies in } \\
\text { six months; E4-4. Asking me to complete the work in three days, I will } \\
\text { definitely complete it in advance, sometimes even two days }\end{array}$ \\
\hline & Task performance & work hard & $\begin{array}{l}\text { E2-6. We all regard the company as our own home, so we work very } \\
\text { hard; E6-15. I worked hard and received unanimous approval of all the } \\
\text { company's employees. The shy little girl had become an outstanding } \\
\text { employee; M2-75. The five employ of Canyou took the electric fan and } \\
\text { placed it on the table. Although the clothes were all wet, they were still } \\
\text { practicing. }\end{array}$ \\
\hline \multirow[t]{3}{*}{ Work performance } & \multirow{3}{*}{ Peripheral performance } & $\begin{array}{l}\text { High organization } \\
\text { output }\end{array}$ & $\begin{array}{l}\text { M3-9. Our software is Carnegie Level } 5 \text { certification, Huawei is only } \\
\text { four, CITIC Communications is three, we are five; M2-64. We have a } \\
\text { company that specializes in film and television effects. It was founded } \\
\text { last year and has already done more than } 12 \text { million businesses; N-1. In } \\
\text { the group's small office, there are various trophies, medals, and pen- } \\
\text { nants }\end{array}$ \\
\hline & & $\begin{array}{l}\text { Collaborate with } \\
\text { each other }\end{array}$ & $\begin{array}{l}\text { E2-42. Saying that I can't do it, what to do, someone will teach you } \\
\text { quickly, or just sitting on a stool and watching how others do it; M2-19. } \\
\text { We have done very well in the management of knowledge, and the inhe- } \\
\text { ritance of the apprenticeship system. }\end{array}$ \\
\hline & & $\begin{array}{l}\text { Willing to do work that is } \\
\text { not scheduled for myself }\end{array}$ & $\begin{array}{l}\text { E3-30. Seeing where the lights are on, they will hurry up and shut off, as } \\
\text { in their own home; E5-24. I am happy to help and guide other col- } \\
\text { leagues. They are unhappy and willing to take the initiative to speak } \\
\text { with me. }\end{array}$ \\
\hline
\end{tabular}


The coding results in Table 6 show that on the one hand, the employees of Canyou show a high degree of emotional dependence on the organization; on the other hand, the dependence of the disabled employees on the organization is also reflected in the salary provided by the organization and the consequence of losing job. In this article, we define emotional dependence as an emotional commitment and the dependency of work and salary as continuing commitment. According to the concept of organizational commitment put forward by Meyer et al. (1991), this article further summarizes emotional commitments and continuing commitment as organizational commitments, which embodies the internalization and identification of specific organizations and their goals by the members of the organization.

Table 7 shows the impact of organizational-level factors on employee performance. This article defines the core category of employee training, device support, and accessibility work environment as instrumental support. The definition of retirement system, home-like friendly atmosphere, understanding of employees with disabilities, and care from disabled employees is emotional support and defined the two as organizational support based on the opinions of Eisengerber and Huntington (1986). The theory holds that the organization's support and recognition of its members is conducive to the emergence of positive emotions such as organizational member satisfaction and loyalty. When an organization member feels support and trust from the organization, it will generate a return intention and further develop a positive attitude and behavior (Pierce et al., 1989).

Table 6. Organizational commitments.

\begin{tabular}{|c|c|c|c|}
\hline Main code & Subcategory & Core category & Initial code example \\
\hline \multirow{5}{*}{$\begin{array}{l}\text { Organizational } \\
\text { commitments }\end{array}$} & & High salary & $\begin{array}{l}\text { M3-26. The salary of the architect is the same as the general manager's. It is } \\
\text { very high; M2-91. The wages are not lower than other companies', and we } \\
\text { are also wrapped around. This is good. }\end{array}$ \\
\hline & $\begin{array}{l}\text { Continuing } \\
\text { commitment }\end{array}$ & $\begin{array}{l}\text { Hard to find new ones } \\
\text { if lose job }\end{array}$ & $\begin{array}{l}\text { E4-8. If a sound person fails, changing a jobs, he can come back again. If a } \\
\text { disabled one falls down, he will only be able to return to the original mea- } \\
\text { ningless life; E5-3. After meeting with Zheng weining, I worked hard to grasp } \\
\text { this rare job opportunity. }\end{array}$ \\
\hline & \multirow{3}{*}{$\begin{array}{l}\text { Emotional } \\
\text { commitment }\end{array}$} & $\begin{array}{l}\text { Income can } \\
\text { subsidize home }\end{array}$ & $\begin{array}{l}\text { E2-40. Most of us were originally a burden to our family. Now we can sup- } \\
\text { port our younger brother to go to college and send money back to buy a } \\
\text { house; E3-51. Now I bought a house in Shenzhen. My parents live with me. }\end{array}$ \\
\hline & & $\begin{array}{l}\text { Workingin Canyou } \\
\text { Can Support oneself }\end{array}$ & $\begin{array}{l}\text { E5-9. After my marriage, I have spent more than I used to . It is imperative } \\
\text { to support myself; N-6. After realizing long-distance employment, they have } \\
\text { stable income every month, and can support themselves }\end{array}$ \\
\hline & & $\begin{array}{l}\text { Have feelings to the } \\
\text { company }\end{array}$ & $\begin{array}{l}\text { M3-61. As long as the company needs them, such as bidding and technical } \\
\text { work, we can call them at any time and they can come back at any time; } \\
\text { N-8Ayinur, a Uighur girl who was diagnosed with cancer, said that she } \\
\text { wanted to move to Canyou for the last one month; E5-59. We live a very } \\
\text { full life every day working, studying, and making friends here. It's just like } \\
\text { home. }\end{array}$ \\
\hline
\end{tabular}


Table 7. Organizational support.

\begin{tabular}{|c|c|c|}
\hline Subcategory & Core category & Initial code example \\
\hline \multirow{3}{*}{ Instrumental support } & $\begin{array}{l}\text { Provides device } \\
\text { support }\end{array}$ & $\begin{array}{l}\text { M3-56. The company's lower limb disabled people are all equipped with wheelchairs; E2-49. If } \\
\text { you want to go to a foreign country or travel, the company will prepare the car in advance; the } \\
\text { car is an outsourced service; E4-27. Staff quarters just below the office. }\end{array}$ \\
\hline & Training for employees & $\begin{array}{l}\text { E3-20. From the moment you come in, you will be assigned a master to see what you are good at; } \\
\text { M3-74. Organize training for disabled employees and open business courses such as website } \\
\text { design production, film and television production, and print advertisement design }\end{array}$ \\
\hline & $\begin{array}{l}\text { Accessible work } \\
\text { environment }\end{array}$ & $\begin{array}{l}\text { M2-10. The surrounding area is a kind of accessible dormitory, and everyone lives very well; } \\
\text { E5-17. The company's accessible office environment allows me to concentrate on my work; } \\
\text { E4-39. Accessibility services are designed in every place, very simple, but also very practical }\end{array}$ \\
\hline \multirow{4}{*}{ Emotional support } & Retirement system & $\begin{array}{l}\text { M2-15. We also have staffs from Tsinghua University, Peking University, and Hunan University. } \\
\text { There are several of them whose muscles stunted, they can't do their work. After they can't do it, } \\
\text { our company raises him; M1-29. As long as this person said that he could not do it, he did not } \\
\text { need medical examination and assessment, we will immediately let him enter the retirement } \\
\text { system. }\end{array}$ \\
\hline & Friendly atmosphere & $\begin{array}{l}\text { M2-64. In the company, we do not call Zheng Weining as chairman. We all call him brother. Like } \\
\text { a loved one, and call me Yongge. N-6. There are no clear rules and regulations for disabled } \\
\text { friends, and there are only ten Family training. All are grateful, sincere, humble, introspective, } \\
\text { etc. M2-37. Whenever their own apricot trees are brought to fruition, they are packed in bed } \\
\text { sheets; and whenever the cold weather arrives, the cruel friends don't forget to send a cart of coal } \\
\text { to the aunt's family. }\end{array}$ \\
\hline & $\begin{array}{l}\text { Understanding } \\
\text { disabled employees }\end{array}$ & $\begin{array}{l}\text { M2-4. The path of each handicapped friend is the same as Liu Yong. They are first mocked and } \\
\text { satirized by others, and then realize their value through an opportunity and a point of their own.. } \\
\text { M1-53. The biggest dream for disabled people is to support themselves. The most unpleasant } \\
\text { thing is to become a burden for the family's life and live without dignity. }\end{array}$ \\
\hline & $\begin{array}{l}\text { Care from the heart } \\
\text { of disabled employees }\end{array}$ & $\begin{array}{l}\text { E2-16. The employees' death, illness, marriage and family are basically big concerns for Zheng; } \\
\text { M1-24. This expenditure compared with the family identity of all employees is insignificant; } \\
\text { M2-37. He took out his house as a "company", a living room office, a bedroom for everyone to } \\
\text { live in. In addition to his salary, he also shouldered the cost of living for everyone. }\end{array}$ \\
\hline
\end{tabular}

Table 8 reflects the psychological changes of the disabled employees after they have worked in the Canyou. First of all, disabled groups can feel equal treatment after they have worked in the group. They don't have to worry about their own shortcomings but only need to develop their own strengths. We define them as equals; secondly, working in Canyou leads the disabled groups to find a way out. With a sense of accomplishment, they can treat each other sincerely and feel their importance to the organization, I define it as self-worth. According to Pierce et al.'s definition of organizational self-esteem: organizational self-esteem is the embodiment of the employee's self-concept in the organization and reflects the employee's judgment and knowledge of his or her position in the organization. We believe that the sub-categories of self-worth and equality can be defined as organizational self-esteem.

\section{Theoretical Integration and Model}

\subsection{Theoretical Integration}

According to the grounded theory research, it is necessary to further abstract the 
Table 8. Organizational self-esteem.

\begin{tabular}{|c|c|c|c|}
\hline Main code & Subcategory & Core category & Initial code example \\
\hline \multirow{5}{*}{$\begin{array}{l}\text { Organizational } \\
\text { commitments }\end{array}$} & \multirow[b]{2}{*}{ Self-worth } & $\begin{array}{l}\text { Treat colleagues } \\
\text { sincerely }\end{array}$ & $\begin{array}{l}\text { E4-47. In the process of communication, we can all open up our hearts and } \\
\text { exchange ideas. } \\
\text { E2-32. When encountering some problems, colleagues, customers, and volun- } \\
\text { teers try their best to help answer them. If they cannot answer, they will also } \\
\text { give their own suggestions. }\end{array}$ \\
\hline & & $\begin{array}{l}\text { I become more } \\
\text { important }\end{array}$ & $\begin{array}{l}\text { E6-45. The whole family came around me and suddenly rotated one life com- } \\
\text { pletely } 360 \text { degrees; E1-59. In the past, people with disabilities depended on } \\
\text { others. Now they can bring many help to others. N-2. The staff of the disabled } \\
\text { friend Abdul Heemann told reporters with excitement: "I can print, write } \\
\text { pictures, and make banners. I can use the six machines in the printing shop. }\end{array}$ \\
\hline & \multirow{3}{*}{ Equality } & $\begin{array}{l}\text { Find a sense of } \\
\text { accomplishment } \\
\text { at work }\end{array}$ & $\begin{array}{l}\text { E5-41. I have become a workable person from a socially disadvantaged group. } \\
\text { There is a platform for me to display my talent and I'm full of pride. E3-42. In } \\
\text { the past, my parents were still worried about me. Now I have wife, children, } \\
\text { and my own house, car and business; E5-39. After work, I feel more confident. } \\
\text { I really enjoy this kind of life. }\end{array}$ \\
\hline & & $\begin{array}{l}\text { Disabled employees } \\
\text { feel a sense of equal }\end{array}$ & $\begin{array}{l}\text { E1-32. In the Canyou company, because we are all disabled people, it is fair to } \\
\text { each other from our heart; E6- } 48 \text {. If I work in a purely commercial company, } \\
\text { even if the salary is high, others will treat me as a disabled person. }\end{array}$ \\
\hline & & $\begin{array}{l}\text { Give full attention to } \\
\text { advantages and } \\
\text { minimize defects }\end{array}$ & $\begin{array}{l}\text { M1-92. In the era of computers, handicapped friends have been made up for } \\
\text { and covered all their disabilities; E2-17. There is no discrimination in this } \\
\text { platform. All of us can use it to shield our physical inconvenience and let us } \\
\text { become a capitalized person through here. E1-53 This kind of work method } \\
\text { that requires almost zero office space and physical fitness seems to be tailored } \\
\text { to me. }\end{array}$ \\
\hline
\end{tabular}

logical relationship between these codes, and describe the behavior phenomena and event contexts in a "story line" manner. This process is also a process of developing a new theoretical framework. According to the typical logic of "stimulus-attitude-behavior", the storyline around "how leadership (stimulus) affects employee performance (behavior) can be summarized as: 1) Spiritual leadership influences employee performance by improving organizational commitment (emotional commitment and continuing commitment) of disabled employees. 2) Spiritual leaders influence their performance by improving organizational self-esteem of employees with disabilities. 3) The effect of spiritual leaders on the performance of disabled employees is influenced by organizational support. The reason why organizational commitments (emotional commitments and continuing commitments) and organizational self-esteem (self-worth and equality) are considered as mediating factors rather than moderating factors, in addition to observing the typical logical paradigm of "stimulus-attitude-behavior", the main reason is Rooted analysis found that there is a clear relationship between leadership and organizational commitment/organizational self-esteem. Just as the interviewed employees said, "We did not initially be loyal to the organization and consider for the company. Instead, it was the spirit of Zheng and the other leaders, as well as their careful and selfless sharing with us that make us be willing to 
do so" (E3). At the same time, "I feel like I'm a wasteful person before working in Canyou, and I can't find my meaning to the society (E4).

It can be seen that the leadership of Canyou Group inspires employees' organizational commitment and organizational self-esteem, and ultimately indirectly affects the performance of employees. Organizational commitment and organizational self-esteem are important mediators that influence the employee's performance. The reason why we regard organizational support as a moderating factor rather than an mediating factor is that through the coding process, the relationship between leadership and employee performance is affected by organizational support. The interviewed disabled employee pointed out that the environment provided by Canyou make up for our physical deficiencies, we can work in peace and complete tasks in this environment, which cannot be imagined in other companies" (E1). Therefore, organizational support plays a moderating role in Canyou' leadership and employee performance.

\subsubsection{Impact path of Organizational Commitment}

Organizational commitment refers to the psychological contract between employees and organizations. Such contracts cannot be expressed in formal documents. Their influence on individuals is an implicit contract and expectation. Through the analysis of the code, it was found that the leadership of "Fostering Staff Beliefs" and "Altruistic Love" of the Canyou company respectively activated employees' emotional commitments and their internal cognitive-driven continuing commitments. Studies have shown that having a high emotional commitment and continuing commitment to the organization can effectively improve employee performance.

Emotional commitment is the employee's psychological attachment to the company and has deep feelings for the organization. The spiritual leader's "alternative love" leadership creates a family atmosphere in the company. Employees have deep feelings and even attachments to the company, and ultimately show a high degree of loyalty to the organization. The leaders of Canyou have always emphasized respect and care. This respect and care are not limited to disabled employees but also include parents of them and social workers who come to serve companies. The leaders of Canyou often provide psychological counseling and services for disabled employees. At the same time, they teach disabled employees to care for their colleagues and social workers. During the research process, some employees said that "there is a company that wants to pay me a high salary, I refuse, and sometimes people are not material, it is a sense of well-being" (E5), shown as Table 9.

It can be seen that once employees have an emotional commitment to the organization, even if their own interests are lost, they are willing to contribute to the development of the organization. At the same time, when they feel concern and care from the leaders, the employees of the company can also easily transfer this feeling to the handling of interpersonal relations in the workplace. They regard colleagues as brothers and sisters and have a harmonious relationship and 
Table 9. Impact path of organizational commitment.

\begin{tabular}{|c|c|c|c|}
\hline Impact path & $\begin{array}{l}\text { The main relationship } \\
\text { structure }\end{array}$ & Relationship structure intention & Typical statement description \\
\hline \multirow{4}{*}{$\begin{array}{l}\text { Organizational } \\
\text { commitment } \\
\text { mediation path }\end{array}$} & $\begin{array}{l}\text { Altruistic Love } \rightarrow \\
\text { Emotional Commitment } \rightarrow \\
\text { Peripheral Performance }\end{array}$ & $\begin{array}{l}\text { Through respecting and concerning for others, } \\
\text { employees and organizations have established } \\
\text { a strong emotional connection, showing a high } \\
\text { degree of dedication and interpersonal promotion. }\end{array}$ & $\begin{array}{l}\text { The company is a big family. Leaders } \\
\text { often teach us to care for each other. If } \\
\text { there is a need for a colleague, even if } \\
\text { it is not the scope of duties, everyone } \\
\text { will do their best to help.(E6) }\end{array}$ \\
\hline & $\begin{array}{l}\text { Belief } \rightarrow \\
\text { Emotional Commitment } \rightarrow \\
\text { Task Performance }\end{array}$ & $\begin{array}{l}\text { Through the encouragement to employees, their } \\
\text { confidence in achieving the goals is enhanced. At } \\
\text { the same time, employees have emotional dependence } \\
\text { on the organization and are willing to actively } \\
\text { complete the work within their responsibilities. }\end{array}$ & $\begin{array}{l}\text { The leaders of the company trust us } \\
\text { very much. Now our feelings to the } \\
\text { company are getting deeper. I will } \\
\text { work hard and live up to the } \\
\text { confidence of the leaders. (E1) }\end{array}$ \\
\hline & $\begin{array}{l}\text { Spirit and Vision } \rightarrow \\
\text { Continue Commitment } \rightarrow \\
\text { Task Performance }\end{array}$ & $\begin{array}{l}\text { Let employees know the company's goals, use the } \\
\text { economic outlook to motivate employees to stay, } \\
\text { and actively complete their work }\end{array}$ & $\begin{array}{l}\text { The company not only solved the } \\
\text { problems of disabled employees, but } \\
\text { also solved social problems. It is worth } \\
\text { my efforts. (E3) }\end{array}$ \\
\hline & $\begin{array}{l}\text { Brief } \rightarrow \\
\text { Continue Commitment } \rightarrow \\
\text { Task Performance }\end{array}$ & $\begin{array}{l}\text { By shaping the employees' beliefs in the realization of } \\
\text { the organization's goals, employees can be confident } \\
\text { that they will have greater economic returns and } \\
\text { actively complete their work. }\end{array}$ & $\begin{array}{l}\text { The development of the company will } \\
\text { surely get better and better. It's very } \\
\text { hard for me to leave such a good } \\
\text { platform, so I must work hard. (E5) }\end{array}$ \\
\hline
\end{tabular}

mutual support. "How can you don't love such a company and cherish it, it is my lifelong ownership, I am willing to support each company leaders and colleagues, and make progress together" (E1). Therefore, the spiritual leader's intermediary role through emotional commitment has a positive effect on task performance and relationship performance.

Continuing commitment is a commitment that employees have to stay in the organization in order not to lose their existing location and benefits. The leader's "spiritual and visioning communication" enables employees to see their posts and their values affect themselves, the company, and the society. While their own interests are fully protected, the benefits of the business are constantly rising. Just as the employee said, "If an employee fails to complete the task, I will work overtime with him because it is related to the company's overall efficiency" (E3). "Employees earn the most profit for the company and the organization can seek for employees' Greatest Happiness (E1). Therefore, "continuing commitment" plays a mediate role between the performance of the disabled employee and spiritual leaders.

\subsubsection{Impact path of Organizational Self-Esteem}

Self-esteem is an individual's comprehensive evaluation of self-worth and ability. As a core component of self-concept, the formation of self-esteem has contextual features. Pierce et al. (1989) proposed the concept of self-esteem based on the organization according to the characteristics of the employees in the organization context, focusing on emphasizing the evaluation of employees' individual perception and self-worth in the organizational context. Spiritual leaders pay attention to the communication of spirit and vision, and encourage disabled em- 
ployees to be confident and enhance the perception of disabled employees about their values in the organization in this process; spiritual leaders' alternative love means cares for employees, telling employees to care for their colleagues, making them experience fair treatment that is not felt in other places, and the two aspects of self-worth and equality together form a sense of high self-esteem of disabled employees. The leader has given his employees great confidence in encouraging them to change their fate with their own personal experience. Just as leaders have stated "people like Yong who is in wheelchairs have steel plates on their backs can achieve their own value, not to mention other s" (E2), "Each disability is the same. As long as you give him a stage, he can realize his own value" (E3). With the encouragement of leaders, employees with disabilities ignore their own flaws, find their own value in the organization, and work harder. Some employees say that "we don't need to worry about other people's perspective on us here, everyone is the same.", shown as Table 10.

Studies have shown that organizational based self-esteem (OBSE) can motivate employees to form positive work behaviors and attitudes. Pan Xiaofu has shown that OBSE is an important factor in promoting the active organizational behavior of employees, Kirkendall and Alarcon shows that OBSE can effectively improve the tracking research of the effectiveness of spiritual leadership, and the performance of high OBSE employees is also prominent in the organization. Therefore, organizational self-esteem plays an intermediary role between spiritual leader and disabled employee performance.

\subsubsection{Impact Path of Organizational Support}

The organizational support theory points out that the organization's support and recognition of employee is conducive to the generation of positive emotions such as organizational satisfaction and loyalty, resulting in positive reward behavior. When the organization members feel support and trust from the organization, they will generate returns. Intent and further positive attitude and behavior. At present, scholars have not come to a unified conclusion on the relationship

Table 10. Organizational self-esteem mediation path.

\begin{tabular}{|c|c|c|c|}
\hline Impact path & The main relationship structure & Relationship structure intention & Typical statement description \\
\hline \multirow{3}{*}{$\begin{array}{l}\text { Organizational } \\
\text { self-esteem } \\
\text { mediation path }\end{array}$} & $\begin{array}{l}\text { Faith } \rightarrow \\
\text { Organizational Self-esteem } \rightarrow \\
\text { Task Performance }\end{array}$ & $\begin{array}{l}\text { By stimulating employees' confidence in } \\
\text { the organization and allowing employees } \\
\text { to see their value in the organization, they } \\
\text { are willing to work hard. }\end{array}$ & $\begin{array}{l}\text { Being able to contribute my strength to the } \\
\text { future development of the company I feel } \\
\text { very fulfilled and I feel very motivated to } \\
\text { work. (E5) }\end{array}$ \\
\hline & $\begin{array}{l}\text { Spirit and Vision } \rightarrow \\
\text { Organizational Self-esteem } \rightarrow \\
\text { Task Performance }\end{array}$ & $\begin{array}{l}\text { By delineating the prospects of the } \\
\text { organization, employees believe that their } \\
\text { abilities can be used to perform their tasks } \\
\text { more actively. }\end{array}$ & $\begin{array}{l}\text { The company's goal is to solve the work } \\
\text { problems of people with disabilities like me. } \\
\text { It's very meaningful for me to give a handful } \\
\text { of help to people with disabilities. (E1) }\end{array}$ \\
\hline & $\begin{array}{l}\text { Altruistic love } \rightarrow \\
\text { organizational self-esteem } \rightarrow \\
\text { peripheral performance }\end{array}$ & $\begin{array}{l}\text { By creating an equal and harmonious } \\
\text { organizational atmosphere, employees can } \\
\text { feel their status in the organization and } \\
\text { are willing to contribute to the } \\
\text { organization. }\end{array}$ & $\begin{array}{l}\text { The atmosphere of the organization is very } \\
\text { good. Everyone is treated equally. I don't feel } \\
\text { a sense of downfall in my heart, and I'm } \\
\text { willing to help my colleagues do something } \\
\text { they can. (E4) }\end{array}$ \\
\hline
\end{tabular}


among leadership, organizational support, and employee performance. Unlike normal employees, support for disabled employees in certain situations comes from the organization as a necessary condition for their job assignments. The theory of Compensation for Functional Disabilities of disabled persons suggests that persons with disabilities can compensate for the loss caused by the loss of certain functions through compensation from other sources. The employees of the group include many different types of disability. They provide instrumental support to compensate for physical defects and provide emotional support to compensate for the more serious mental problems among the disabled. This has an important role on disabled employees. The interviewed employees stated that "the organization has provided us with an accessible work environment in which we are not able to be overwhelmed by our own physical disabilities and can concentrate on doing something meaningful to the organization" (E4), embodies the importance of organizational support to employees with disabilities. Therefore, the organization supports play a moderation role in the relationship between spiritual leaders and employees with disabilities, shown as Table 11.

\subsection{Theoretical Model}

In general, when managers show a certain type of leadership, they affect the mental and attitude of disabled employees firsts, and then influence their behavior. Specifically, when the manager is a spiritual leader who pays attention to the spirit \& vision, has a firm belief in the employee, and respects and cares for others, the disabled employee will have a high organizational commitment and high organizational self-esteem. This series of positive attitudes will have a positive effect on their behavior, that is, higher employee performance. Unlike normal employees, employees with disabilities have their own deficiencies. Even though they have a positive attitude under the leadership of a spiritual leader, enterprises still need to provide support from the organizational level to the disabled to help them overcome their own shortcomings. It will transform the positive attitude of the organization into the productivity of the organization. This paper proposes the following substantive theoretical model, as shown in Figure 1 below.

\section{Research Significance and Management Inspiration}

\subsection{Research Significance}

Through the study of grounded theory, this paper explores the influence

Table 11. Organizational Support moderate path.

\begin{tabular}{llll}
\hline Impact path & $\begin{array}{l}\text { The main relationship } \\
\text { structure }\end{array}$ & $\begin{array}{l}\text { Relationship structure } \\
\text { intention }\end{array}$ & Typical statement description \\
\hline $\begin{array}{l}\text { Organizational } \\
\text { Support moderate path }\end{array}$ & $\begin{array}{l}\text { Spiritual leader } \rightarrow \\
\text { employee performance }\end{array}$ & $\begin{array}{l}\text { Through the organization's support for } \\
\text { employees, spiritual leaders will play a } \\
\text { greater role in employee performance }\end{array}$ & $\begin{array}{l}\text { Zheng and Yong have been inspiring us with } \\
\text { their actions, providing us with such a good } \\
\text { work and living environment, and working }\end{array}$ \\
\hline
\end{tabular}




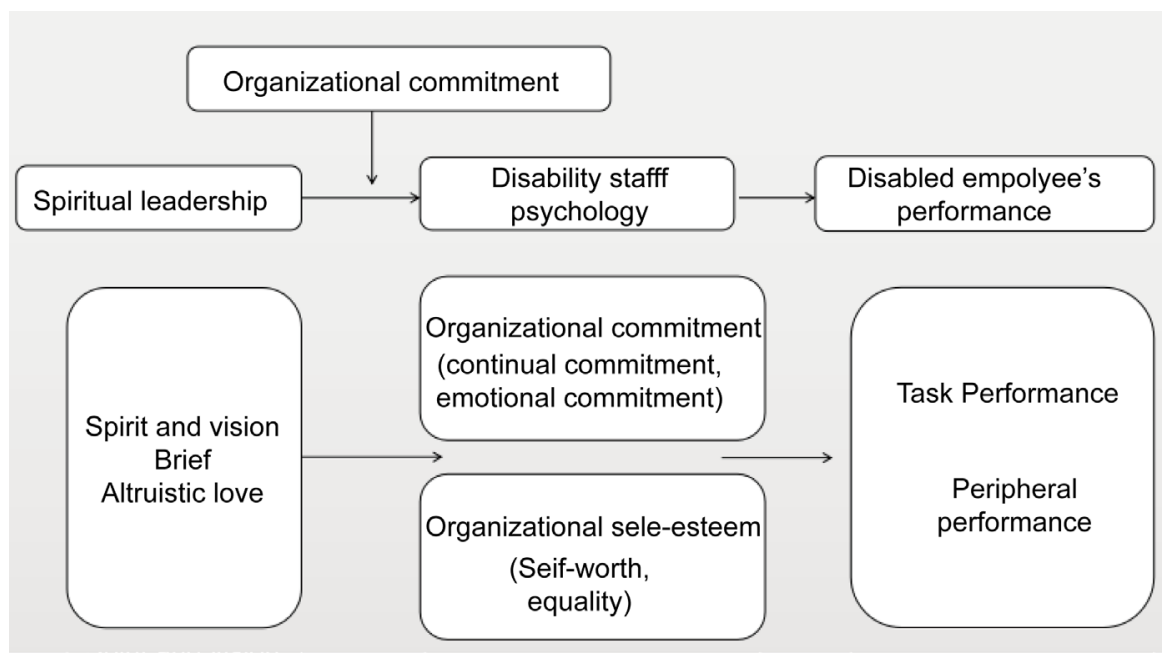

Figure 1. Theoretical model.

mechanism of spiritual leadership on the performance of disabled employees. It not only reflects the importance of leadership to corporate management, but also reflects the psychological appeal of disabled employees and ordinary employees. The interaction of various dimensions of spiritual leadership has inspired the active mental attitudes of disabled employees, thereby affecting the work performance of disabled employees, achieving the business goals of them and also solving the psychological problems of most disabled employees. It is of great theoretical significance and Practical significance.

\subsubsection{Theoretical Significance}

At present, the theoretical study on the employment of disabled persons in China lags behind the actual development rate of them. In the field of employment of disabilities, although the theoretical research involved in various perspectives, but was lack of enterprise-level scientific research .In general, it still remains at the stage of phenomenon explanation and phenomenon description at the social level. By comprehensively reviewing relevant papers home and abroad, we found that the theoretical system for the employment of disabilities in China is not mature enough. This research takes the current domestic representative social enterprise-Canyou as the target audience and discusses the influence mechanism of leadership on the performance of disabled people. From the perspective of advantageous, this paper introduces theoretical results such as organizational support, organizational self-esteem, organizational commitment, and grounded theory research methods, which tries to provide new ideas and paradigms for the employment problem of disabled persons in China.

\subsubsection{Practical Significance}

First of all, this paper establishes that the proper leadership not only can stimulate the enormous potential of disabled employees, but also can improve the psychological problems of the disabled. It is an extension of the existing leadership theory. 
Secondly, from the perspective of advantage, this paper regards disabled employees as a group that can compete with non-disabled employees in the organization, and reflects the potential production of disabled groups. On the one hand, the results of this study can stimulate management's confidence in disabled staff and encourage them to change the way they treat them, thereby maximizing the productivity of disabled staff. On the other hand, the results of this study can stimulate the confidence of other entrepreneurs in the society for disabled people. In this era of diversified and inclusive entrepreneurship, they can provide more opportunities and platforms for disabled people and promote the social employment of the disabled.

Finally, the research results of this paper show that the appropriate leadership has a great improvement on the mental attitudes of the disability groups. The research on disabilities' psychology has always considered that social worker behavior is an effective way to improve the mental health of the handicapped. However, few studies have focused on the impact of organizational situations on the mental health of disabled people. This will provide new ideas for the development of disability businesses.

\subsection{Management Inspiration}

First of all, establish an advantageous perspective on the employment of disabled persons, guide the public to correctly understand the disabled and actively support the employment of disabled persons. The leaders of the Canyou Group re-evaluated the disabled groups from a positive perspective, realized the effective embedding of their employment, and improved the employment welfare and living standards of the disabled. The "advantageous perspective" should be taken as the basic concept and value option for the policy development and their work for disabled persons. On the basis of equality, disabled persons should be involved in social life and economic construction, and gradually cultivate the concept of employment. In the process of participation, they can gain their own development, integrate into social life, and ultimately share social responsibility with other members of society.

Secondly, leaders should shape a work environment based on humanistic values and focus on the spiritual appeal of disabled employees. Rogers, a humanistic psychologist, points out that everyone has a "realization tendency," which is an internal demand that points to growth, enabling all the natural potential and all its properties of an individual to be realized. Although the physical conditions of the handicapped are not able to reach the level of a sound person, they are equal to those who are healthy in the spirit level. People with disabilities also have human dignity and rights, and have the desire to participate in social life. Therefore, paying attention to the spiritual needs of disabled people is a necessary prerequisite for stimulating their own potential, improving their quality of life, their overall quality and their happiness index.

Finally, focus on the needs of disabled employees and establish multidimen- 
sional support of the company. The theory of compensation for functional disabilities points out that persons with disabilities can use their other aspects to reduce the loss caused by some losing functions. By organizing support for disabled employees, it will greatly reduce the difficulty of working for them. Specifically, we should meet the specific needs of disabled staff, provide support for them to solve their worries, dilute their own deficiencies, call on other employees to care and help them and expand the channels for pressure release so as to better develop the productive potential of them.

\section{Research Limitations and Outlook}

As an exploratory study, this article also has some limitations. The first is the theoretical saturation problem. This paper adopts a single case grounded research. Although a representative company is selected to collect data from multiple sources, it can only guarantee the theoretical saturation of individual samples, and it will inevitably affect the external validity of the research. Subsequent research needs to add other samples, carry out comparative studies of multiple cases, and continuously enrich and improve the theory developed in this paper so that it can reach a more extensive sense of saturation.

Secondly, the purpose of this paper is to explore the theoretical construction of the influence of leadership on the performance of disabled employees, without quantitatively testing. Next, a quantitative data validation model can be further used to compensate for the lack of qualitative analysis.

Finally, this paper discusses the impact of leadership on the performance of disabled employees from a qualitative point of view. Whether the corporate culture and the performance of disabled employees are inextricably linked needs to be verified by quantitative research in the future.

\section{Conflicts of Interest}

The authors declare no conflicts of interest regarding the publication of this paper.

\section{References}

Bernardin, H. J., \& Beatty, R. W. (1984). Performance Appraisal: Assessing Human Behavior at Work. Kent Human Resource Management.

Borman, W. C. (1993). Expanding the Criterion Domain to Include Elements of Contextual Performance. N. Schmitt \& W.C. Borman Personnel Selection in Organizations.

Brown, G. W., Andrews, B., Harris, T. et al. (1986). Social Support, Self-Esteem and Depression. Psychological Medicine, 16, 813-831. https://doi.org/10.1017/S0033291700011831

Charmaz, K. (2009). Constructivist Grounded Theory Methods. In Developing Grounded Theory: The Second Generation. https://doi.org/10.1037/e493882008-001

Clive, F. (2011). Performance Appraisal and Management: The Developing Research Agenda. Journal of Occupational \& Organizational Psychology, 74, 473-487. https://doi.org/10.1348/096317901167488 
Katz, D., \& Kahn, R. L. (1966). The Social Psychology of Organizations. Administrative Science Quarterly, 46, 118. https://doi.org/10.2307/2575337

Meyer, J. P., Bobocel, D. R., \& Allen, N. J. (1991). Development of Organizational Commitment during the First Year of Employment: A Longitudinal Study of Pre- and Post-Entry Influences. Journal of Management Official Journal of the Southern Management Association, 17, 717-733. https://doi.org/10.1177/014920639101700406

Motowidlo, S. J., \& Van Scotter, J. R. (1994). Evidence that Task Performance Should Be Distinguished from Contextual Performance. Journal of Applied Psychology, 79, 475480. https://doi.org/10.1037/0021-9010.79.4.475

Pierce, J. L., Gardner, D. G., Cummings, L. L. et al. (1989). Organization-Based Self-Esteem: Construct Definition, Measurement, and Validation. Academy of Management Journal, 32, 622-648. https://doi.org/10.2307/256437

Saleebey, D. (1996). The Strengths Perspective in Social Work Practice: Extensions and Cautions. Social Work, 41, 296-305.

Stogdill, R. M. (1948). Personal Factors Associated with Leadership; A Survey of the Literature. Journal of Psychology, 25, 35. https://doi.org/10.1080/00223980.1948.9917362 